\title{
CORPORAL PUNISHMENT: CASE STUDY ON THE LEGITIMACY OF CORPORAL PUNISHMENT IN JUNIOR HIGH SCHOOL "X" SURABAYA
}

\author{
Agus Wahyudi, Warsono \\ Universitas Negeri Surabaya \\ e-mail: masaguslumos@gmail.com
}

\begin{abstract}
Teacher and students have relations that cannot be separated in education. The relationship between the two sometimes runs harmoniously but in different occasion it is contradictory. Frequently, teachers do corporal punishment to students. The teacher claimed that is to enforce discipline for students at school. This paper reveals how the form of corporal punishment performed by teachers to students and the intention of teachers in committing corporal punishment to students, as well as how the legitimacy of such acts of violence are constructed. This research was conducted in junior high school "X" Surabaya by using phenomenology approach by Alfred Schultz (1991). This case study used a descriptive qualitative approach. The data collection techniques were in the form of observation and interview.
\end{abstract}

Keyword: corporal punishment, case study, legitimacy of violence

Abstrak: Guru dan siswa memiliki hubungan yang tidak dapat dipisahkan dalam pendidikan. Hubungan antara keduanya terkadang berjalan dengan harmonis tetapi dalam kesempatan yang berbeda itu kontradiktif. Seringkali, guru melakukan hukuman fisik kepada siswa. Guru mengklaim bahwa hal tersebut dilakukan untuk menegakkan disiplin bagi siswa di sekolah. Makalah ini mengungkapkan bagaimana bentuk hukuman fisik yang dilakukan oleh guru kepada siswa dan niat guru dalam melakukan hukuman fisik kepada siswa, serta bagaimana legitimasi tindakan kekerasan tersebut dibangun. Penelitian ini dilakukan di SMP "X" Surabaya dengan menggunakan pendekatan fenomenologi oleh Alfred Schultz (1991). Studi kasus ini menggunakan pendekatan kualitatif deskriptif. Teknik pengumpulan data berupa observasi dan wawancara.

Kata kunci: hukuman fisik, studi kasus, legitimasi kekerasan

\section{INTRODUCTION}

Educational environments such as schools should provide a safe place for children. Therefore, such deplorable acts of violence between students as well as between students and teachers must be prevented. This intended to create a safe and comfortable education environment. But the fact shows many cases of violence are found in schools. Data from the Indonesian Child Protection Commission (KPAI), as reported by Kemendikbud, from January 2011 to July 2015 there were 1,880 cases of violence had occurred in the educational environment (Kompas, January 15, 2016).

In 2011, there were 276 violent acts had occurred in schools. The numbers were increased in 2012 to 552 cases of violence. In the following year, the number of school violence dropped to 371 cases. However, in 2014, there was an increase number of violence in schools with 461 cases. On July 2015, there were 220 cases of violence occurring in schools (Kompas, January 15, 2016).

Discipline is frequently to be a benchmark of 'image' and the quality of education in a 
formal educational institution such as a school, so that educators must work hard to make regulation for students. The various ways they accomplish to enforce discipline in school, such as giving tough and strict sanctions for students who violate the regulations such as; ditching, smoking in the school neighborhood, coming late to school and others. Even so, there are still many students who violate the rules. Moreover, teachers do violence to make the students in order to follow the rules.

The results of research conducted by UNICEF (2006) shows that several regions of Indonesia, $80 \%$ of the violence occurred to students which performed by teachers. Despite the fact that teachers are the 'second parents' of students in school, they should create a comfortable environment, safest and the best place for students.

The level of violence at elementary education is reinforced by data from the survey conducted by the Indonesian Child Protection Commission (KPAI) during the last 2 years (2015-2016). They affirmed that the most events of violence by teachers to the student occur in elementary education (Rukmorini, in http:// kompas.co.id/read/xml, 2016). In addition, based on the data from National Education Department (Depdiknas) the quality of primary school teachers in Indonesia, only $38 \%$ are eligible for teaching (Kompas, January 25, 2017).

A study conducted by Yayasan Kesejahteraan Anak Indonesia (YKAI) found, although only a case that was exposed to mass media, quantitatively there is a tendency for increased number of violence to children. In 2014, there were 172 cases, in 2015 increased to 421 cases and in 2016 there were 476 cases. It is noteworthy that although year-to-year the data on violence of children's rights is increasing, but when it is compared to developed countries the numbers the violence recorded in Indonesia are minimal. For example, in the United States there are approximately 500,000 children who are treated destructively every year (Humsona, 2016. p 55).

In developed countries such as the United States, Child Abuse cases can be detected fairly well because the law obliged doctors and teachers to report child abuse cases to the authorities. The term and case of Child Abuse itself had been known in the public around the 1960s, when the medical world was surprised by the report Henry Kempe (1962) in the Journal of the American Medical Association about the wrong treatment experienced by children, as many as 302 cases in 71 hospitals, of which 33 children died and 85 children suffered permanent brain damage (IG.N. Gede Ranuh, 2009).

Forms of violence that are generally experienced to students are physical violence. It is a form of violence that can cause injury to students, such as hitting, torturing, slapping and others. Psychological violence that is emotionally violent such as: insulting, harassing, criticizing or saying words that hurt feelings, hurting self-esteem, lowering confidence, making people feel contemptible, small, weak, ugly, useless and helpless. Another form of violence is called defensive violence. It is carried out in the framework of protection measures and not assault actions. The last is an aggressive violence an action to get something like act of rob (Rini, 2008).

Teachers in Indonesia frequently impose penalties ranging from minor sentences to severe penalties in teaching learning process such as, glaring of the eyes to the painful blow. Many different form of punishments, however, these remains one, this make consist of painful ele- 
ments for both body and soul. This can be seen at Malang on November 11, 2011, where the principal named Samsul forced his two students to sit down in a circle of fire as a punishment just because 2 students entered the classroom through the window (Malang Pos, 11 November 2011). Violence with excessive punishment was also made by a teacher named Rohani Susiwi at the State Elementary School 23 Tugu Utara Jakarta. She was reported to the Indonesian Child Protection Committee (KPAI) on September 5, 2012 for beating four of her students because they did not do homework. As a result, KPAI tries to mediate the interests of parents and students; it also plans to re-establish the physical and psychological consequences of the victims (Kompas, 5 September 2012).

Another case that is quite attracted the attention of the Mayor and politicians in the House of Representatives Building took place in, Surabaya by the end of June 2011. The school principal of Tandes Lor Elementary School, named Wahyuningsih, was complained by dozens of her students for cursing with dirty words, cursing her students with ill titles, thieves, insulting the parents' profession, and even hit her students. Interestingly, the school principal did the same thing to her' relatives teachers and staff. She argues that her action was still in the educational corridor. She added that the demonstration conducted by his students is only a matter of misperception (Jawa Pos, 27 June 2011).

Violence committed by teachers at schools is often justified by the community as a part of the process of educating children. Even, parents argue, it is a form of education to provide and encourage disciplinary value to students. Though any form of punishment for learners, in the short term, will affect to students' the concen- tration, perception and behavior. So far, the students are lazy to go to school. In the end, the learners stay class or quit school. Psychologically, punishment in educational institutions can cause children to be traumatized or antipathy towards education. When this negative circle keep goes on, it can effect to culture of violence in society (Syamsuarni, 2006).

In addition, violence to children in the home environment was dominated by mothers. From 194 cases, 32.5\% of both physical and psychological violence were committed by the mothers, while $6.18 \%$ were performed by fathers. This is done as a form of punishment, build discipline and as an outrage of parents' anger in children. The parents believe that it has philosophically value; it is for establishing discipline for children's future. Traditionally, physical punishment has been accepted as one of the most effective methods of controlling and disciplining children. This is supported by people who believe that physical punishment is important to prevent moral degradation, both within the household and the community (Susilowati, 2008).

In the field of education the forms of violence occur through different practices and do by different actors. Mapping the doer of violence in the field of education involves: individuals, institutions and countries. Each of the actors has different motivations, goals and manifestations of violence. The three actors are directly and indirectly involved in perpetuating violence to students. Violence that many occur in the school environment caused by several factors such as, first, the curriculum is quite dense and heavy. This makes the student must learn various things within the specified time. The existing curriculum strongly forces the students to follow and pursue the achievement of 
the curriculum, although it is not relevant to the child's ideals (Wijono, 2011).

Secondly, teachers have many of problems. They are key figures in education; in fact many of them are not worthy to teach. The low level of intellectuality of the teacher, but they are forced to achieve curriculum targets. Furthermore, the struggles of life make some teachers have not been able to manage negative emotions so that they can treat learners roughly (Rakib, 2011).

Based on the above facts, it can be seen that the violence performed by teachers is frequently occurred in the form of non-physical rather than physical. Even, non-physical violence done often but these are not reported. This is because the difficulty of finding evidence. Sometimes, this because either the government, the community or teachers did not consider that it is incorrect thing. Commonly, this will get attention when there is scars or when the victim should be treated in hospital because he/she is in critical condition.

From the initial exposure, the writer is interested to observe the violence that occurred in educational institutions. Regarding that educational institution should be able to solve problems without violence. Since the main function of educational institutions is as a place to educate and give good teaching by teachers to their students. So all forms of problems concerning with the structure and system of educational institutions can be solved by means of educating, not by violence.

Based on the various exposures cases above, the writer will reveal the form of violence and the teachers' intention to legitimize the actions performed by the teachers to students. It is expected that the results of the study can be beneficial for knowing the form of teacher violence on the students. So that in the future it does not cause misunderstanding between the teacher, parents, students and the school concerned.

\section{METHOD}

This research uses qualitative method with case study approach with phenomenology perspective by Alfred Schultz (1971). In this approach, researchers create complex images, examine the words, detailed reports of subject views, and conduct studies on natural situations (Creswell, 1998: 15). This research took place in the junior high school " $X$ " Surabaya since in the school the corporal punishment become model of habit that has never been questioned by parents and community surrounding. Data collection techniques are by using observations and in-depth interviews. The technique analysis uses Phenomenology from Alfred Schultz (1971), which states that phenomenology is the way an individual or group to understand the consciousness and actions of the individual or group.

\section{RESULTS AND DISCUSSION}

\section{Using of Corporal Punishment in Education}

According to $\mathrm{WHO}$, violence is the use of physical force and power, threat or action against self, individual or group of people who cause or most likely cause bruises, deaths, psychological losses, developmental disorders or deprivation of rights (Bagong S. et al.: 2000, p.27-28).

Violence is a term that is full of meaning of "suffering" whether it is studied in a psychological perspective or in a legal perspective; it contains human behavior (person/group of people) that can cause suffering for others (personal or group). Violence or violence by Jerome 
Skolnick defined as "an ambiguous term meaning is established through political" In terms of behavior, Michael Levi then called violence as "....its content and cause are socially constructed...”. From this point of view, it seems that the formulation of acts of violence is very much related to cruel and inhuman behavior, but it becomes obscure whether it also accommodates the aspirations of minorities (women and children) who have been vulnerable to violence (John Darak P., 2010, p.41).

Various forms of violence experienced by students, involves physical violence is a form of violence that can cause injury or injury to students, such as hitting, torturing, and others. Then psychic violence that is emotionally violent is done by insulting, harassing, criticizing or saying words that hurt feelings, hurting selfesteem, lowering confidence, making people feel contemptible, small, weak, ugly, useless and helpless. Physical violence is a human body hurt physically. While psychic violence is a pressure intended to reduce mental and mental ability (Galtung, 2003: 29).

The data found that some teachers in SMP Unggulan "X" Surabaya did acts of physical violence such as: run around the school yard, push up and sit up. Forms of violence occurred in the school environment, Some students' claimed that the physical abuse experienced by them are in the form of: squat around the field 10 to 20 rounds, or walk up and down from upstairs to downstairs of school buildings, clean up the whole school yard, clean up the students' toilets and teachers', and push up. In addition, they also experienced to have beat, slap, tweaking (jeweran in Javanese) from the hands, feet, and buttocks.

Not only the physical violence suffered by some of students but also the psychic violence he had received. As the writer found there were some students who wear a "red vest". This aimed to make ashamed them among his friends. Due to severe psychological violence, some students confessed they suffered from sleep disorder or eating disorder, self-harm, mentally disorder in the form of loss of contact with reality such as schizophrenia, sense of helplessness, loss of confidence, and loss of ability to act.

Violence that occurs to students at school can lead various consequences, namely:

a. Physical: physical violence causes the student's organs to suffer damage such as bruises, injuries, etc.

b. Psychological: trauma, fear, insecurity, resentment, decreased spirit of learning, concentration, creativity, loss of initiative, and endurance (mental) students, lack of confidence, inferior, stress, depression, etc. In the long term, this impact can be seen from the decline in achievement, change in persistent behavior.

c. Social: students who experienced acts of violence without any treatment, may go away from the social environment, fear, feel threatened and feel unhappy. They also become quiet, have difficulties to communicate with both teachers and friends. So far, they are not easy to trust others, and being an introvert characteristic, stay away from the association (Wiyani, 2012: 27).

Violent acts can have many impacts. The following are some of the statement of some of the students of Junior High School "X". The effect of physical abuse was in the form of a scar and a tired feeling. While the psychic violence resulted feeling of embarrassed since the students were being punished in front of friends, feeling of depression because the teacher frequently scolded, even the students felt fear 
and traumatic when they should meet with the horrible teacher.

\section{Legitimacy of the corporal punishment is Con- structed}

Understanding on how the teachers legalization act of corporal punishment is constructed from the fundamentalist educational ideology used by the school teachers. O'neil described that for a fundamentalist ideology of education follower, contemporary society is faced with a moral collapse in the future, and the highest imperative to do is overhauling conventional beliefs and behavior benchmarks by way of returning to the higher merits of the past (O’Neil, 2002. p.247).

The form of violence in schools is structural violence in the form of systematic exploitation along with mechanisms that hinder the formation of consciousness and hinder the presence of institutions that can oppose exploitation and oppression. Therefore, this kind of violence is more hidden and more dangerous. Injustice, oppressive policies, discriminatory legislation are forms of structural violence. Structural violence manifests in the form of power imbalances that cause inequality in life. Some cases place teachers as perpetrators of violence. In Galtung approach, this violence is a direct form of violence in which learners become victims of violence due to the application of educational curriculum.

Galtung (2003: 27) divides the typology of violence into three namely; direct violence, cultural violence, and structural violence. Direct violence is an event; structural violence is a process; while cultural violence is something permanent. This condition leads to an image of violent strain of violent phenomenology. Cul- tural violence is the most basic strata and a source of inspiration for structural violence and direct violence. The next strata of structural violence are the rhythms of violence and the patterns of cultural violence. At its peak, the visible violence of is the direct violence perpetrated by humans against others. Institutionalized violence exists in context, systems and structures, such as discrimination in education, employment, health care. The factors that can affect to the occurrences of violence are: the students are naughty or stubborn then various internal problems of the teacher such as the demands of discipline, the target of score above the students' ability, creating positive value for school or for the best result of accreditation and even for the application of curriculum, basic competencies, and indicators set up by central and local government so that the school is required to create a target that has been planned and determined.

The policy of determining the educational curriculum that resulted in violence in schools is a form of structural violence. Just as some teachers have discovered from the interview of the curriculum content, it also affects a teacher to commit acts of violence against his/her students. One of the junior high school teachers of "X" Surabaya revealed that after having seen the demands of the government on education in Indonesia which should be equated with other countries to advance the country of Indonesia, students are required to achieve good score. Structural violence is intended to be indirect violence, which is not derived from a particular person, but which has been formed within a particular social system.

This violence is occurred and connected in the view of Peter L. Berger through social (cultural), and structural (societal) aspects. 
Moreover, structural violence is not necessarily by through physical. Just as what researchers found in the school yard about the rules of a classroom teacher about the basic competencies or indicators that must be taken by students in one semester.

The teacher's basic competence of reference was derived from the central education policy which requires every teacher in the school must possess basic competency guideline that should be achieved in every one semester of subject. The objectives of competence are made as a reference of students to achieve the target value to be taken. So that students can continue the lesson to the next level. This policy of competence makes the teachers extra-strict to create a design of learning process so that students can achieve the indicators that have been applied. If not then students who cannot reach the target value determined will be left behind subjects.

This leads to structural violence actions that the victims are students who are less understood the lessons. They will be left behind from his friends who are smart to understand the lesson. The structural violence comes from government policies and it is implemented in schools and runs by teachers in the classroom. Some students feel discriminated, they cannot enjoy the learning process and receive knowledge well in the school.

Structural violence is a form of direct violence in which learners become victims due to the application of educational curriculum. However, teachers should be able to generate a positive first impression and stay positive for the next days. Teachers' attitudes and behavior is very important for the students' progress and spirit in learning. Punishment done by the teacher will be a negative impression that also have negative impact in students learning process. No matter how small the impact that arises on the practice of violence in education, it is still a mistake. School should be a place for students to grow.

Violence conducted by the teachers in schools can also lead to pros and cons among the public or educators themselves. Violence at school should not be published to the audiences. When it has already spread among the people. The society should also be keen to observe the real phenomenon. This indicates that when there is effect, it must be there is cause.

The policy of determining the educational curriculum that resulted in violence in schools is a form of structural violence. Structural violence is intended to be indirect violence, which is not derived from a particular person, but which has been formed within a social system. This violence operates through social, cultural, and (factor) structural (community) values. The regulation is often to be the reason why teachers make discipline their students in order get a high score. Students are demanded to learn more with actual time that is unbalanced. This makes the students feel under pressure. In other word it is a form of non-physical violence such as getting bad grades teachers will scold or even harass, insulting in front of other students.

\section{Rationalization of Violence}

If it look at all activities carried out in the classroom controlled by a teacher, because the teacher has more authority to regulate and stabilize class conditions. If an action is obtained that students deviate from the rules, of course, will be subject to a penalty, which is usually done directly. 
Verbal acts of violence such as "yelling", are the actions most often carried out by a teacher. The teacher's confrontation is often done by the teacher because the act of "shouting" has become a habit that aims to remind students to return obediently and orderly. It is not uncommon for a teacher to discipline students in rough ways such as "beating". This action becomes a habit of a teacher to discipline his students. Sometimes this action is not too much thought that it is actually an act of violence that has a bad effect on students. Some students themselves argue that the actions taken by the teacher are still considered as a natural thing to do because it is disciplining students, but it is also the duty of the teacher to make students obey in any activity at school. If you examine further about acts of violence committed by teachers against students. A teacher's actions are rational, because in such a way students will feel that they have made a mistake. In summary and simply can be described in the following scheme:
A teacher has the right to organize and discipline his students, the process of individual discipline is the key that shows the character of modern society. Instrumental rational action in this type of social action can be used to examine further about acts of violence committed by teachers against students. When referring to the phenomenology of Alfred Schultz, the reasons that can be justified because of the motive and the reasons that are the expectations of the teacher by the acts of violence committed (in order to motive) to students become responsible society and aware of the laws and rules that bind them, so as not to become wild learners.

Rational is defined by the researcher as an attitude that is naturally carried out because there is a reality behind the emergence of acts of violence. Instrumental becomes a tool that is used as a basis on the basis of an action. Violence is a rational act, as happens in class, a teacher will be angry if he finds students who are not good. The teacher acts rationally, as

\section{Rationalization Scheme of Acts of Violence Committed by Teachers against Students}

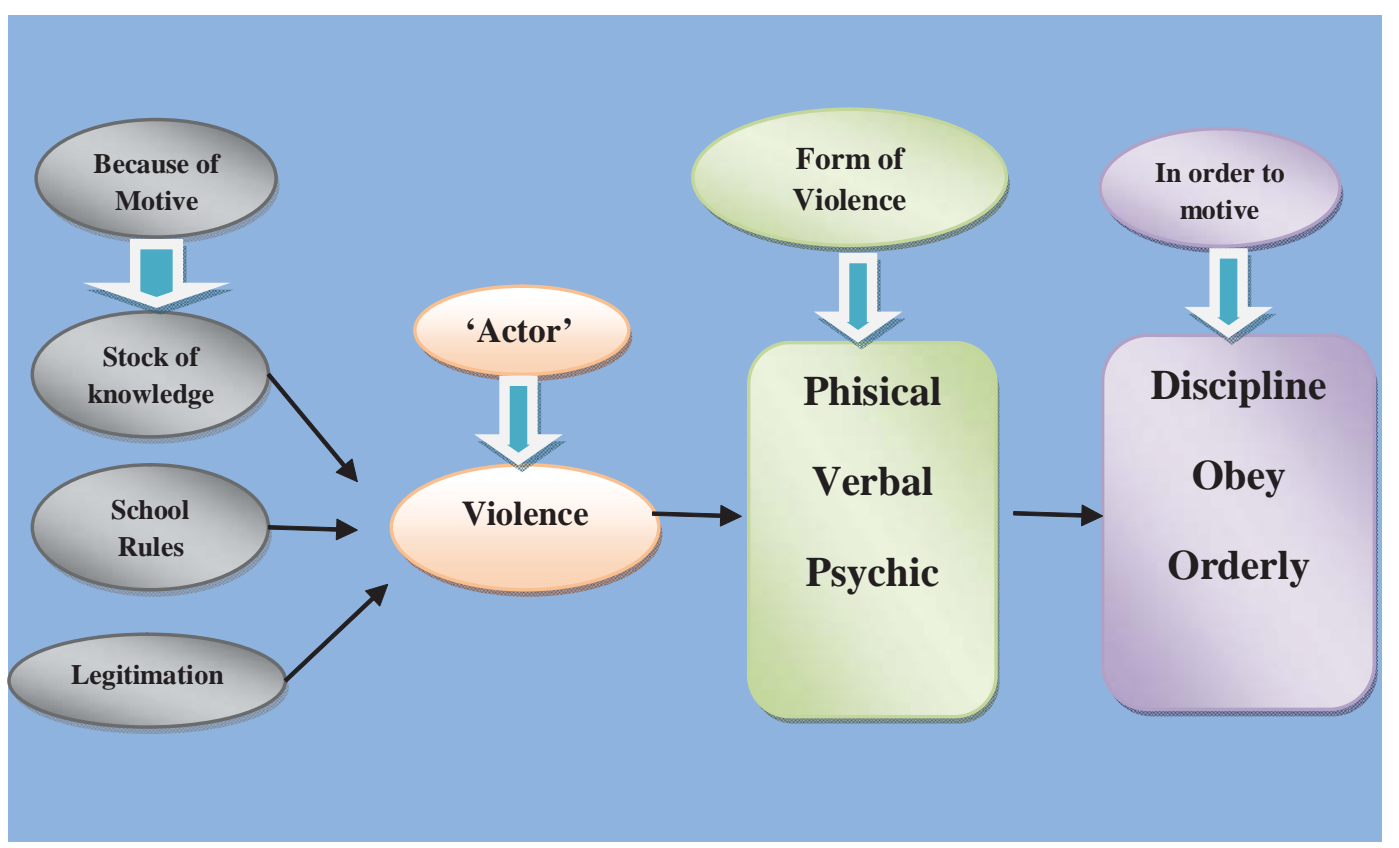


seen from his anger describing the purpose so that students return to obedience after receiving a reprimand hard done by the teacher. Discipline is not solely prioritizing physical punishment, but this is the process for changing individuals to act according to expectations.

The development of understanding of the use of punishment as an instrument in the framework of behavior change methods is seen through the emergence of an rehabilitative paradigm. The paradigm sees that someone who violates or deviates from the existing rules is basically a person who is broken, sick, deficient, troubled, or has an inability to do the behavior. Therefore, through punishment, the person basically wants to be repaired or healed of his shortcomings. Along with this paradigm shift, forms of punishment also develop, vary, and are said to be increasingly humane.

Associated with the situation of people who see punishment, and not shame, as a means of social control, it is suspected that there are certain cases and certain subjects where the situation makes people (perhaps also to groups of people) feel ashamed, perhaps more effective. Manners, social values and morality are things that traditionally can be regarded as something that, if violated or if it is known to be violated, will bring shame to the perpetrator. The problem is, even though the Indonesian people are people who supposedly have high courtesy, have high social values and claim morality, shaming seems almost never used. Shame itself can indeed be a deterrent to certain actions, but it is known to have been developed very little in order to react due to certain actions (in the hope of being a deterrent in time).

The current macro situation is a specific situation encountered in the context of secondary school education, which is known in forms ranging from student delinquency (e.g. cheating), brawls, involvement with drugs and early sexual activity. These things generally make this group an object of affirmative action or decisive action from the school through the teacher. This is what then becomes the PR of education with the teacher as the spearhead in responding to it, borrowing the term education character, Warsono (2017) teacher with his soul calling to be a humanist, critical, creative, and altruistic educator. By developing educational aesthetics, it is not only a matter of uniformity, but is developing the art of educating unique and diverse psycho-social people who are entrusted to their religion, family, country, and society (Warsono, 2017.p.9).

If referring to Skinner's perspective in operant conditioning, acts of violence committed by the teacher. If reinforcement strengthens the behavior, punishment or punishment stops the behavior by presenting an aversive stimulus (giving an unpleasant stimulus) which can take the form of punishing by pinching, and so on. As the facts found by the author in this study as revealed by the following $\mathrm{Mr}$. $\mathrm{H}$;

“... when I was tall, the students became silent ... fear ... there was someone who had bruised ... imprinted on the face as a result of my head ... there was also his mouth until bloody ... that's what I did because it was really outrageous, the part I often hit his buttocks, pinched his stomach, jewer ears ... well, if it goes too far and the final reflex is just like that ..... miss ... repeated - repeat ............. and he did it immediately I heard it and I knew the voice of the child .... "

Skinner agrees that the future effects of punishment are more difficult to predict. One effect of punishment is suppress behavior on someone who is given a punishment, which can cause the person to become very suffering, angry, aggressive, or other negative emotional reactions, even they may hide evidence of their 
wrong behavior or escape from the bad situation. Once expressed by one of the students when experiencing such stressful conditions must try to run away (run away) from school by jumping the school fence. Feeling guilty and pressured in such a way, rather than having to deal with a teacher who has wiped out punishment for the violations they have committed. As revealed by one of the following students:

\footnotetext{
“... I once ran away and jumped through the back of the school fence, I don't want to ... sir, should Mr. Bach play a hand ... at that time, I mocked my friend to cry ... but the next day I was called my homeroom teacher but I didn't hit it ... just crossed it ... ".
}

In this study there are indications that students who experience violence from their teachers, become 'ignorant children' by repeating violations and facing a different model of punishment given by the teacher. As the findings in this study indicated by the statement of one teacher;

".... the case that this student has done several times ... this student does not give up (deterrent) repeating the same mistake. Even though the student has been suspended, he still makes another mistake. Even though the suspension has not been completed, it has been added with other errors and violations. Before going to that stage ... I used to be bald first, usually I did during the flag ceremony on Monday. After it's finished ... my friends enter their new class I petali (shaved), in the box i ... ben (to be ashamed) to his friends ... if it has been shaved off it shows that those who have being defaced has committed a serious violation. Men or women are the same, if women are cut off like policewomen. On Monday they will be graduated by wearing a red vest so that all students know that this child is at the end of the horn...."

It can be understood that the actions of teachers to students in this study as positive reinforcement given the motives underlying the action as a result/response of conditions and situations such as (so that students are not wild). As shown in the findings of the following data revealed by one teacher;

“....... Application of physical punishment to students is still needed. This is due to the varied backgrounds of students. Some only with advice or reprimand do not violate the rules. But not infrequently there are those who will not break the rules if given physical punishment. However, we as educators remain within reasonable limits when giving physical punishment. This means that the physical punishment that we apply does not make the students physically disabled and when we give physical punishment we do it in a safe and body area such as pinching. If left to the present children become wild, behave badly... ".

\section{Conclusion}

The policy of establishing an educational curriculum that results in acts of violence in schools is a form of structural violence. Besides physical violence, there is also psychological violence. Violence against students or among students, especially psychic violence, can cause children to experience psychological trauma, the spirit of learning can decrease which can result in the maximum learning outcomes achieved by students. Violence occurred in a learning process in the form of physical and psychological. Sometimes teachers commit acts of violence to learners on the grounds of punishment for establishing discipline. Teachers use physical force that results in physical injury. This physical violence, at some stage, can also be a form of psychic violence. Students who experienced physical violence will be traumatized. Various internal problems of the teacher such as the demands of various forms of discipline, achievement of high score for students, creating a good value for school or the achievement of the best accreditation result, even the 
application of curriculum, basic competencies and indicators set up by the central government and area, so the school party is required to create a target that has been planned and determined. The policy of determining the educational curriculum that resulted in the occurrence of violence in schools is a form of structural violence. Beside, physical violence there is also psychic violence. Psychic violence, can cause students to experience psychological trauma, decreased learning spirit which can result in learning outcomes achieved by learners that is not optimal.

\section{Suggestion}

The education without any violence action is described as a third alternative after acting of blame and violence. An educator who knows the error of a student, has three choices afterwards, whether he/she will blame him/her, use violence to force students to correct the error or the third, do a nonviolent way.

Refraining from blaming is certainly not an easy matter for adults when knowing a mistake made by a student. But keep in mind that an accusation to students will somehow effect to student, since she/he instinctively will defend himself. Student's reaction to be one thing that is feared will lead an action of violence from teachers to students.

\section{REFERENCES}

Assegaf, Abd. Rahman. 2004. Pendidikan Tanpa Kekerasan: Tipologi Kondisi, Kasus dan Konsep. Yogyakarta: Tiara Wacana.

Ballard, M., Argus, T., \& Remley, T.P. 1999. Bullying and Violence: a Proposed Prevention Program. NASSP Bulletin, 83, 38-47.
Coloroso, Barbara. 2007. Stop Bullying: Memutus Rantai Kekerasan Anak dari Prasekolah hingga SMU. Diterjemahkan oleh: Santi Indra Astuti. Jakarta: PT Serambi Ilmu Semesta.

Crouch, Julie. L, Joel S. Milner, Cynthia Thomsen. 2011. Childhood Physical Abuse, Early Social Support, and Risk for Maltreatment: Current Social Support As a Mediator of Risk for Child Physical Abuse. Child Abuse and Neglect, Volume 25, Issue 1. Department of Psychology, Northern Illinois University.

Denzin, Norman K., Yvonna S. Lincoln. 2011. The Sage Handbook of Qualitative Research. Penerbit Pustaka Pelajar.

Dharmawan, Tommy. 2010. Penerapan Hukuman Terhadap Peningkatan Kedisiplinan Siswa di Sekolah (Studi Kasus di Sekolah Menengah Atas Negeri Situraja): Skripsi Universitas Pendidikan Indonesia.

Gusti. 2011. Kasus Kekerasan di Sekolah Kian Meningkat. Diakses dari http://www.ugm. ac.id/id/berita/3371kasus.kekerasan.di. sekolah.kian.meningkat pada tanggal 24 Februari 2014, Jam 17.03 WIB.

Holt, Melissa K. e.g. 2007. Hidden Form of Victimization in Elementary Students Involved in Bullying. School Psychology Review, ProQuest Education Journals. Vol. 36, No.3.

Humsona, Rahesli. 2016. Situasi Krisis dan Munculnya Fenomena Kekerasan. Jurnal Dinamika, Vol. XX No. 1. Surakarta: Fakultas Ilmu Sosial dan Ilmu Politik, Universitas Sebelas Maret.

Jenson, M.J. \& Dieterch, W.A. 2007. Effects of a Skills - Based Prevention Program on Bullying and Bully Victimization among Elementary School Children. Prevention sciences, 8, 285-296. 
Levianti. 2008. Konformitas dan Bullying pada Siswa. Jurnal Psikologi, Vol. 6, No. 1.

Lexy J. Moleong. 2007. Metodologi Penelitian Kualitatif. Bandung: Rosdakarya.

Milles, Mattew B. \& A. Michael Huberman. 2009. Analisis Data Kualitatif.

Moustakas, C. 1994. Phenomenological Research Methods. London: SAGE Pub.

Ningtyas, Ayu Dian. 2009. Perlindungan Hukum Terhadap Anak Korban Pemukulan Guru di Lingkungan Sekolah. Skripsi: Universitas Airlangga.

O’Neil, William. 2002. Ideologi-Ideologi Pendidikan (Alih Bahasa Omin Intan Naomi). Yogyakarta: Pustaka Pelajar.

Olweus, D. 1998. Violence among Children in School: We Know and What We Do, Zagreb: School book. 596 Bisera Jevtic et al. Procedia - Social and Behavioral Sciences, 141 (2014) 587-596

Ponny Retno Astuti. 2008. Meredam Bullying: 3 Cara Efektif Menanggulangi Kekerasan pada Anak. Jakarta: PT Grasindo.

Rokib, Muhammad. 2011. Ketentuan Hukuman Fisik Terhadap Anak-Anak di Dalam Undang-Undang Perlindungan Anak dalam
Penerapan Disiplin). Disertasi: UIN SSK Riau.

Santoso, Thomas. 2002. Teori-Teori Kekerasan. Jakarta: Ghalia Indonesia.

Sejiwa. 2008. Bullying: Mengatasi Kekerasan di Sekolah dan Lingkungan Sekitar Anak. Jakarta: PT Grasindo.

Setyawati, Ika. 2010. Kekerasan Terhadap Anak (Studi Deskriptif tentang Bentuk Kekerasan, Reaksi, dan Dampak Kekerasan Terhadap Anak di Pondok Pesantren). Skripsi. Surabaya: Universitas Airlangga.

Shri, Heddy Ahimsa-Putra. 2001. Latar Budaya Tindak Kekerasan terhadap Anak-Anak di Indonesia. Jurnal Manusia dan Dinamika Budaya: Dari Kekerasan sampai Baratayudha, Yogyakarta. Fakultas Sastra UGM.

Warsono. 2017. Guru: Antara Pendidik, Profesi, dan Aktor Sosial. The Journal of Society \& Media, Vol. 1(1), 1-10.

Widayanti. 2009. Fenomena Bullying di Sekolah Dasar Negeri di Semarang. Jurnal Psikologi. Vol. 5. No. 2, Desember 2009.

Windu, I. Marsana. 1992. Kekuasaan \& Kekerasan menurut Johan Galtung. Bandung: Kanisius. 